\title{
Front Matter: Volume 9494
}

, "Front Matter: Volume 9494," Proc. SPIE 9494, Next-Generation Robotics II; and Machine Intelligence and Bio-inspired Computation: Theory and Applications IX, 949401 (24 June 2015); doi: 10.1117/12.2199012

SPIE Event: SPIE Sensing Technology + Applications, 2015, Baltimore, MD, United SPIE. States 


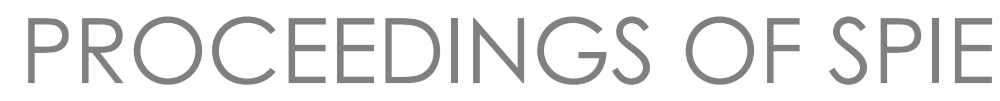

\section{Next-Generation Robotics II; and Machine Intelligence and Bio-inspired Computation: Theory and Applications IX}

Dan Popa

Muthu B. J. Wijesundara

Misty Blowers

Editors

21-22 April 2015

Baltimore, Maryland, United States

Sponsored and Published by

SPIE

Volume 9494 
The papers included in this volume were part of the technical conference cited on the cover and title page. Papers were selected and subject to review by the editors and conference program committee. Some conference presentations may not be available for publication. The papers published in these proceedings reflect the work and thoughts of the authors and are published herein as submitted. The publisher is not responsible for the validity of the information or for any outcomes resulting from reliance thereon.

Please use the following format to cite material from this book:

Author(s), "Title of Paper," in Next-Generation Robotics II; and Machine Intelligence and Bioinspired Computation: Theory and Applications IX, edited by Dan Popa, Muthu B. J. Wijesundara, Misty Blowers, Proceedings of SPIE Vol. 9494 (SPIE, Bellingham, WA, 2015) Article CID Number.

ISSN: 0277-786X

ISBN: 9781628416107

Published by

SPIE

P.O. Box 10, Bellingham, Washington 98227-0010 USA

Telephone +1 3606763290 (Pacific Time) · Fax +1 3606471445

SPIE.org

Copyright (C) 2015, Society of Photo-Optical Instrumentation Engineers.

Copying of material in this book for internal or personal use, or for the internal or personal use of specific clients, beyond the fair use provisions granted by the U.S. Copyright Law is authorized by SPIE subject to payment of copying fees. The Transactional Reporting Service base fee for this volume is $\$ 18.00$ per article (or portion thereof), which should be paid directly to the Copyright Clearance Center (CCC), 222 Rosewood Drive, Danvers, MA 01923. Payment may also be made electronically through CCC Online at copyright.com. Other copying for republication, resale, advertising or promotion, or any form of systematic or multiple reproduction of any material in this book is prohibited except with permission in writing from the publisher. The CCC fee code is 0277-786X/15/\$18.00.

Printed in the United States of America.

Publication of record for individual papers is online in the SPIE Digital Library.

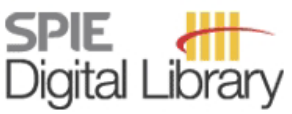

SPIEDigitalLibrary.org

Paper Numbering: Proceedings of SPIE follow an e-First publication model, with papers published first online and then in print. Papers are published as they are submitted and meet publication criteria. A unique citation identifier (CID) number is assigned to each article at the time of the first publication. Utilization of CIDs allows articles to be fully citable as soon as they are published online, and connects the same identifier to all online, print, and electronic versions of the publication. SPIE uses a six-digit CID article numbering system in which:

- The first four digits correspond to the SPIE volume number.

- The last two digits indicate publication order within the volume using a Base 36 numbering

system employing both numerals and letters. These two-number sets start with 00, 01, 02, 03, 04, $05,06,07,08,09,0 A, 0 B \ldots$.. OZ, followed by 10-1Z, 20-2Z, etc.

The CID Number appears on each page of the manuscript. The complete citation is used on the first page, and an abbreviated version on subsequent pages. 


\title{
Contents
}

\author{
$\checkmark$ Authors \\ vii Conference Committees
}

\section{Part A Sensors for Next-Generation Robotics II}

\section{SESSION $1 \quad$ NEW SENSORS FOR ROBOTS}

949403 EHD printing of PEDOT: PSS inks for fabricating pressure and strain sensor arrays on flexible substrates [9494-2]

949404 Multi-material additive manufacturing of robot components with integrated sensor arrays [9494-3]

949405 Micro-force sensing mobile microrobots [9494-4]

949407 Force estimation in a 2-Dof piezoelectric actuator by using the inverse-dynamics based unknown input observer technique [9494-26]

\section{SESSION 2 ROBOTIC APPLICATIONS}

949408 Sensor study for high speed autonomous operations [9494-6]

949409 Multi-modal sensor and HMI integration with applications in personal robotics [9494-7]

94940A Robotic situational awareness of actions in human teaming [9494-8]

9494 OB Performance evaluation and clinical applications of 3D plenoptic cameras [9494-9]

9494 OC Surface EMG and intra-socket force measurement to control a prosthetic device [9494-10]

9494 OD Resolving ranges of layered objects using ground vehicle LiDAR [9494-11]

9494 OE Performances analysis of piezoelectric cantilever based energy harvester devoted to mesoscale intra-body robot [9494-28]

9494 OF Untethered microscale flight: mechanisms and platforms for future aerial MEMS microrobots [9494-30]

\section{SESSION 3 CONTROL}

9494 OG Automated actuation of multiple bubble microrobots using computer-generated holograms [9494-12] 
$9494 \mathrm{OH}$ An ontology to enable optimized task partitioning in human-robot collaboration for warehouse kitting operations [9494-13]

9494 Ol Control of a powered prosthetic device via a pinch gesture interface [9494-14]

9494 OK Multi-mode vibration suppression in 2-DOF piezoelectric systems using zero placement input shaping technique [9494-27]

9494 OL Simultaneous suppression of badly damped vibrations and cross-couplings in a 2-DoF piezoelectric actuator by using feedforward standard $H_{\infty}$ approach [9494-29]

\section{Part B Machine Intelligence and Bio-inspired Computation: Theory and Applications IX}

\section{SESSION 1 ADVANCES IN FUNDAMENTAL RESEARCH}

9494 OM Evolving spiking neural networks: a novel growth algorithm exhibits unintelligent design [9494-16]

9494 ON Experimental analysis of a Lotka-Volterra neural network for classification [9494-17]

949400 Collaborative mining and transfer learning for relational data [9494-18]

SESSION 2 INNOVATIONS IN APPLIED RESEARCH

9494 OS Bio-inspired approach for intelligent unattended ground sensors (Best Paper Award) [9494-21]

SESSION $3 \quad$ IMPROVED SITUATIONAL AWARENESS

9494 OU Subset selection of training data for machine learning: a situational awareness system case study [9494-23]

9494 OV Realistic computer network simulation for network intrusion detection dataset generation [9494-24]

9494 OW Change detection in Arctic satellite imagery using clustering of sparse approximations (CoSA) over learned feature dictionaries [9494-25] 


\section{Authors}

Numbers in the index correspond to the last two digits of the six-digit citation identifier (CID) article numbering system used in Proceedings of SPIE. The first four digits reflect the volume number. Base 36 numbering is employed for the last two digits and indicates the order of articles within the volume. Numbers start with 00, 01, 02, 03, 04, 05, 06, 07, 08, 09, 0A, 0B...0Z, followed by 10-1Z, 20-2Z, etc.

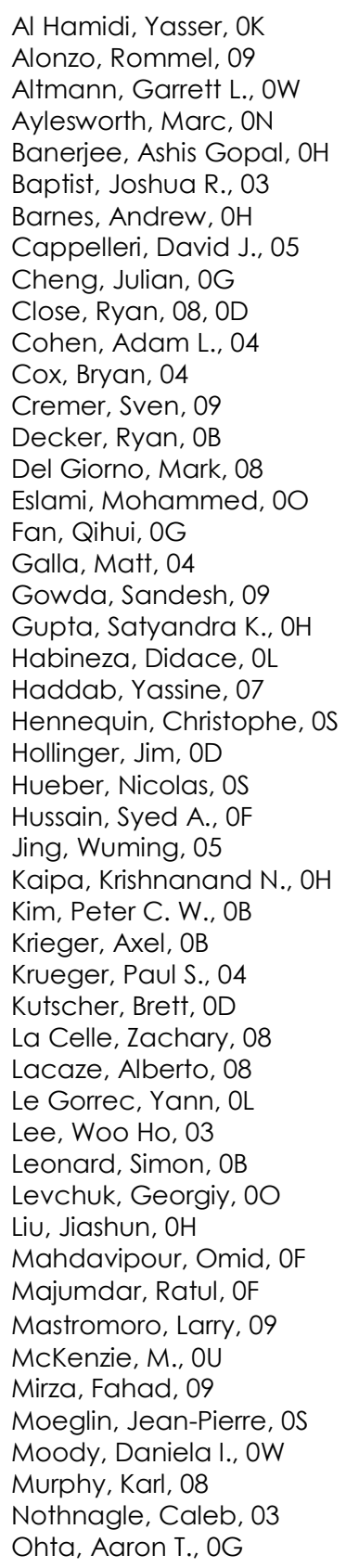


Proc. of SPIE Vol. $9494949401-6$

Downloaded From: https://www.spiedigitallibrary.org/conference-proceedings-of-spie on 26 Apr 2023 Terms of Use: https://www.spiedigitallibrary.org/terms-of-use 


\title{
Conference Committees
}

\author{
Symposium Chair \\ Wolfgang Schade, Clausthal University of Technology and Fraunhofer \\ Heinrich-Hertz Institute (Germany) \\ Symposium Co-chair
}

Ming C. Wu, University of California, Berkeley (United States)

\section{Part A Sensors for Next-Generation Robotics II}

\section{Conference Chairs}

Dan Popa, The University of Texas at Arlington (United States)

Muthu B. J. Wijesundara, The University of Texas at Arlington Research Institute (United States)

Conference Program Committee

Ashis G. Banerjee, GE Global Research (United States)

Ryan R. Close, U.S. Army RDECOM CERDEC NVESD (United States)

Yong-Lae Park, Carnegie Mellon University (United States)

Micky Rakotondrabe, FEMTO-ST (France)

Veronica J. Santos, University of California, Los Angeles

(United States)

\section{Session Chairs}

1 New Sensors for Robots

Muthu B. J. Wijesundara, The University of Texas at Arlington Research Institute (United States)

2 Robotic Applications

Ryan R. Close, U.S. Army RDECOM CERDEC NVESD (United States)

3 Control

Ashis Gopal Banerjee, GE Global Research (United States) 


\section{Part B Machine Intelligence and Bio-inspired Computation: Theory and Applications IX}

Conference Chair

Misty Blowers, Air Force Research Laboratory (United States)

Conference Program Committee

Gus Anderson, MacAulay-Brown, Inc. (United States)

Georgiy M. Levchuk, Aptima, Inc. (United States)

John A. Marsh, State University of New York Institute of Technology (United States)

Clare D. Thiem, Air Force Research Laboratory (United States)

Robinson Pino, U.S. Department of Energy (United States)

Daniel Stambovsky, Air Force Research Laboratory (United States)

Jonathan Williams, Air Force Research Laboratory (United States)

Bryant T. Wysocki, Air Force Research Laboratory (United States) 